\title{
NEW DATA REGARDING THE QUESTION OF INTERREGIONAL CONTACTS IN THE IRON AGE. RESULTS OF A SURFACE SURVEY IN CZECHY, KRAKÓW DISTRICT
}

\begin{abstract}
Dulęba P., Wysocki P. 2016. New data regarding the question of interregional contacts in the Iron Age. Results of a surface survey in Czechy, Kraków district. Sprawozdania Archeologiczne 68, 301-325.

Surface surveys on a newly, accidentally discovered site in Czechy, Kraków district, yielded a large series of finds associated with the Przeworsk culture settlement. Its chronology ranged from the younger Pre-Roman Iron Age all the way to the early Migration Period. The detailed surface survey revealed numerous imports from the Celtic and Dacian settlement zones, as well as items of a provincial Roman origin. The finds presented in the paper indicate that the most intensive contacts with areas south of the Carpathians might be dated to the final stage of the La Tène period and the turn of the early and late Roman Iron Age.
\end{abstract}

Keywords: settlement finds - metal jewellery and garment accessories - Roman coins - pottery - younger Pre-Roman Iron Age - Roman Iron Age

Received: 11.01.2016; Revised: 17.03.2016; Accepted: 6.05.2016

The discovery of a Celtic coin hoard in Czechy, Kraków district, made most probably in 2011 (Dulęba and Wysocki, in print), demonstrated an urgent need to conduct surface surveys at the site. Their main goal was to verify the information obtained from amateur investigators. In 2013 and 2014 regular surface surveys took place, which resulted in identifying a new archaeological site designated as Czechy 17. The investigation revealed traces of a set-

\footnotetext{
* Institute of Archaeology, Wrocław University, Szewska st. 48, 50-139 Wrocław, Poland; przemdul@gmail.com

** Tarnobrzeska st. 3/3, 30-681 Kraków, Poland; stepowyduch@gmail.com
} 
tlement of at least 4 ha, which had been used in three phases. The first one might be associated with the late Bronze Age and early Iron Age Lusatian culture, the second with the Przeworsk culture and the third might be dated to the late medieval and early modern period. To boost the accuracy of the observations and cross-check the results, the surveys within the whole investigated area were conducted three times, in three different seasons.

Site 17 is located within the Szreniawa River valley on a clearly visible promontory, partially eroded by the river. The finds were recorded on the fields in the top part of the promontory, within the administrative borders of villages of Czechy and the neighbouring Niegardów, Proszowice district (Figs. 1-2). In the immediate vicinity of site 17 in Czechy an (only partially) overlapping site of Niegardów 1 (with finds only from the Neolithic and Early Bronze period) is located. Both of the sites are also situated on a separate morphological form of terrain. The documentation of the latter is available in the AZP system.

The Szreniawa River valley area was intensively used throughout the whole of prehistory - all the way from the Neolithic period (Kruk 1970). Therefore the relatively large number of finds recorded during the investigations did not come as a surprise. The survey yielded 60 special finds, the vast majority of which might be associated with the Przeworsk culture settlement. Most of them were metal items but some glass, clay and bone specimens have also been recorded.

\section{ARCHAEOLOGICAL SOURCES}

1. Bimetallic fibula, partially preserved, iron (?) part of the pin and iron (?) spring missing, bow diamond-shaped in cross-section, catch decorated with ribs, length $3,5 \mathrm{~cm}$, bow width o,4 cm, type K according to J. Kostrzewski; (Fig. 3:1).

2. Fibula made of copper and tin alloy with large percentage of the latter (so-called "white metal"), partially preserved (pin and spring missing), bow oval-shaped in crosssection, decorated with three rings, head with a flash, length $4,7 \mathrm{~cm}$, bow width $0,3 \mathrm{~cm}$, hybrid specimen of a Schüsselfibel and type A 65 - Mailhac variant according to H. Meller; (Fig. 3:2).

3. Bronze fibula, partially preserved (spring and pin missing), bow diamond-shaped in cross-section, decorated with a ring, catch partially preserved and decorated with ribs, length 4,5 cm, bow width o,3 cm; type O according to J. Kostrzewski; (Fig. 3:3).

4. Fragment of a bronze fibula, part of the eight-coiled spring and the head preserved, width $2 \mathrm{~cm}$; type A 68; (Fig. 4:1).

5. Fragment of a bronze fibula, part of the spring and part of the flat, band-shaped bow preserved, spring width 2,7 cm, bow width 1,2 cm, type A 57-63; (Fig. 4:2).

6. Fragment of a bronze fibula, partially melted, preserved parts: profiled foot, part of the catch and part of the bow decorated with a triangular plate, length $2,4 \mathrm{~cm}$; group IV/V according to O. Almgren; (Fig. 4:3). 


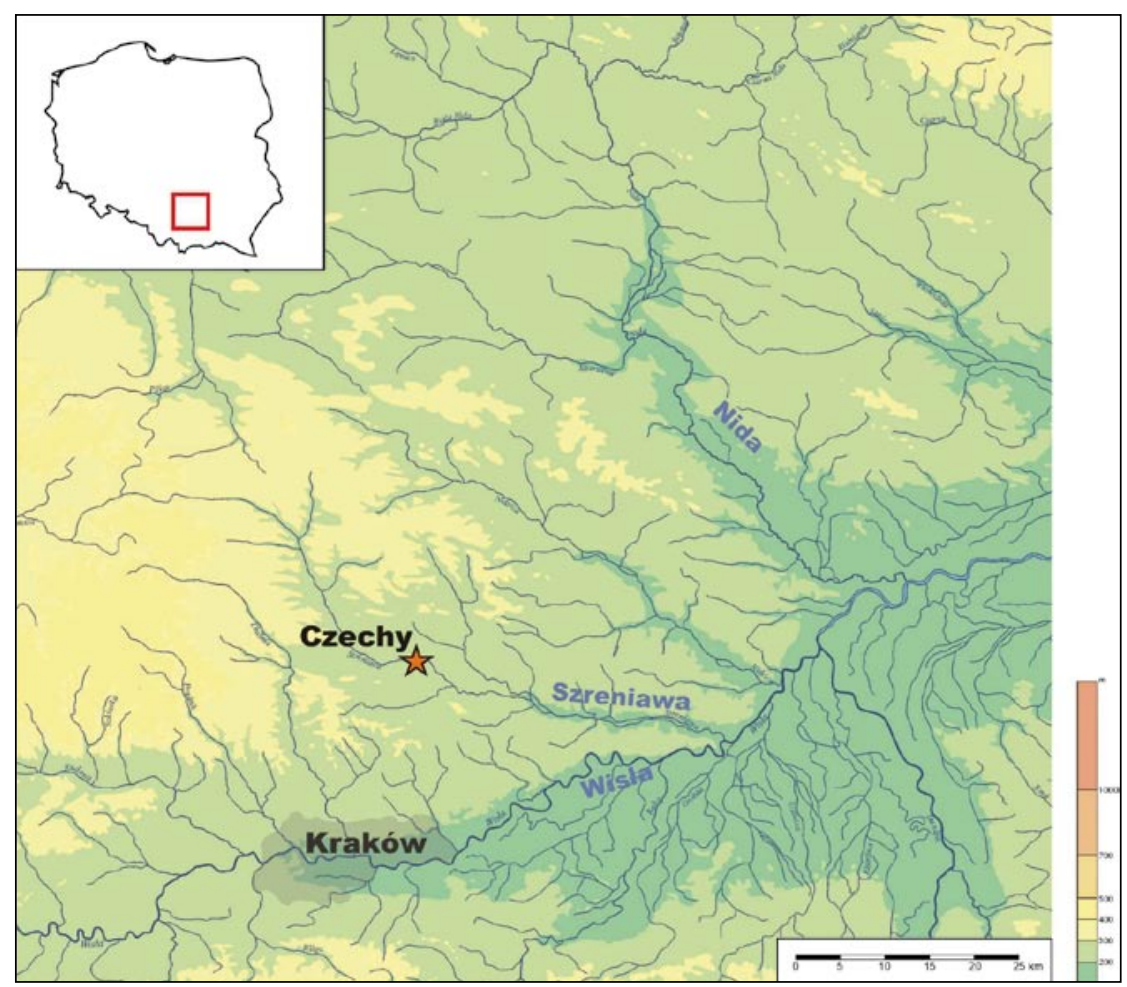

Fig. 1. Location of the site in Czechy (drawing P. Dulęba)

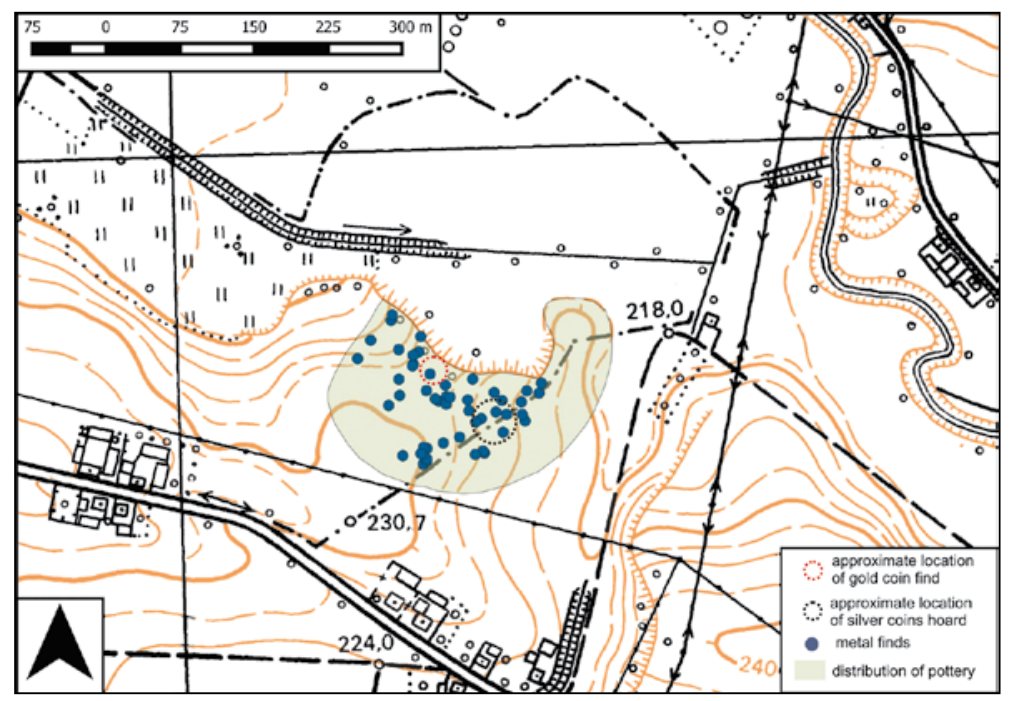

Fig. 2. Planigraphy of the finds from surface surveys (drawing P. Dulęba) 


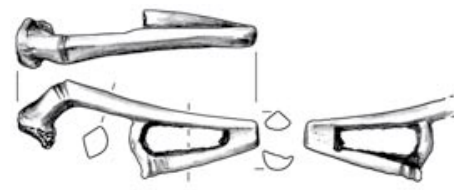

1
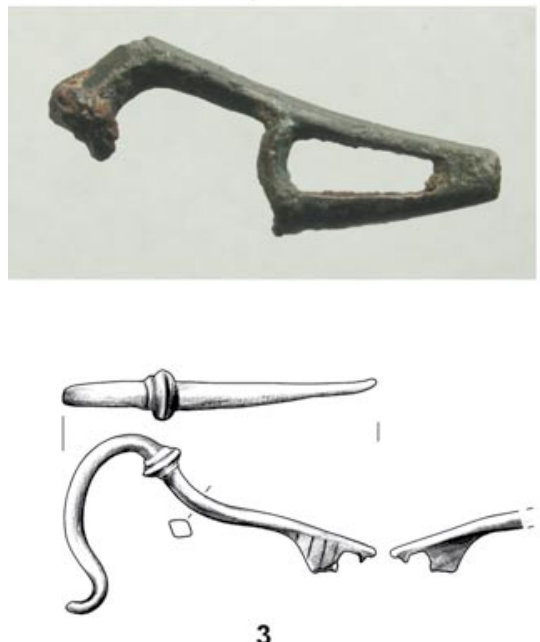

3
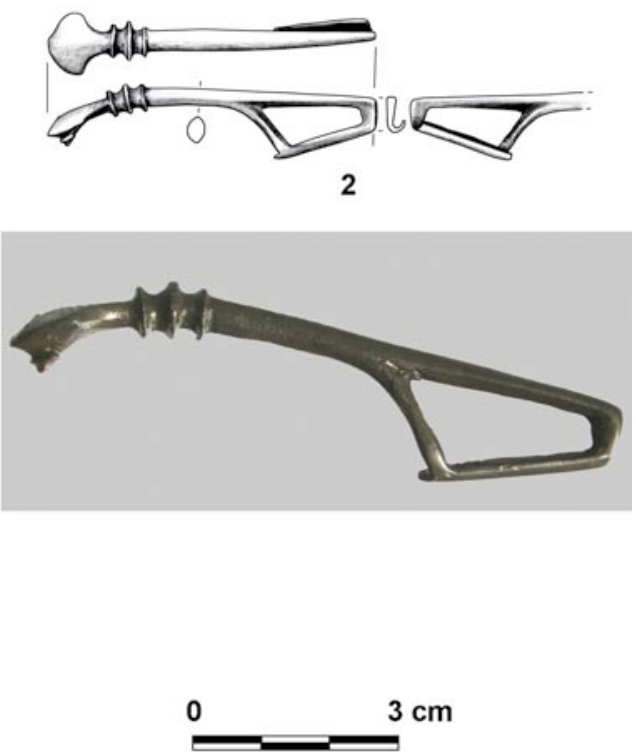

Fig. 3. Fibulae from Younger Pre-Roman period: 1, 3: bronze, 2: white metal (drawing N. Lenkow, photo P. Dulęba) 


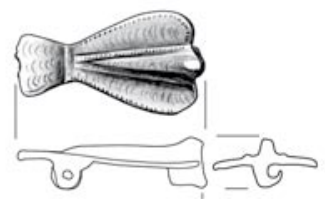

1

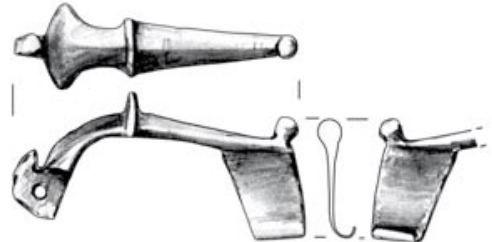

2

0 $3 \mathrm{~cm}$

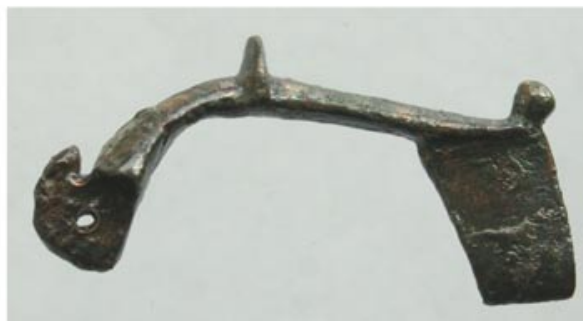

Fig. 5. Fibulae from Roman period. 1-2: bronze (drawing N. Lenkow, photo P. Dulęba) 

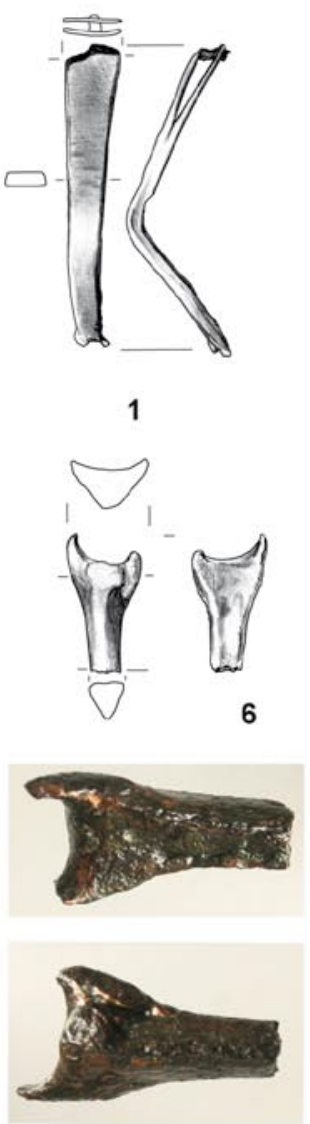
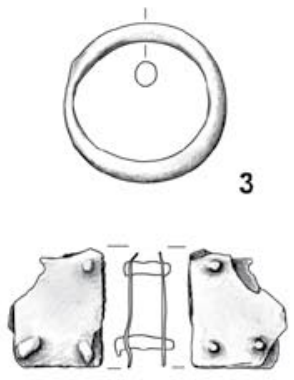

4
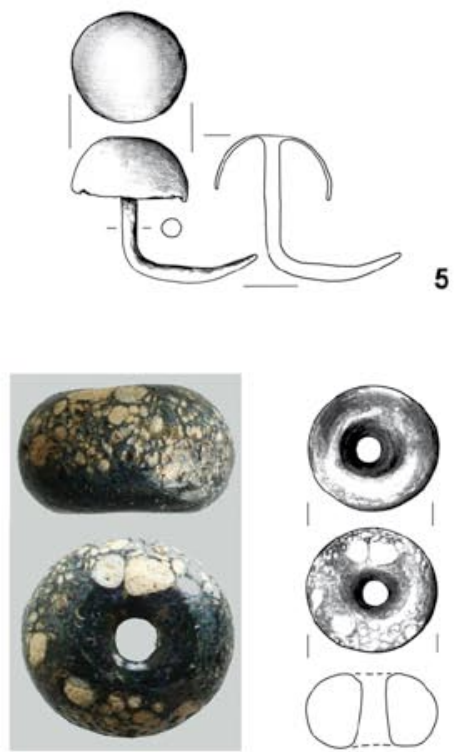

8
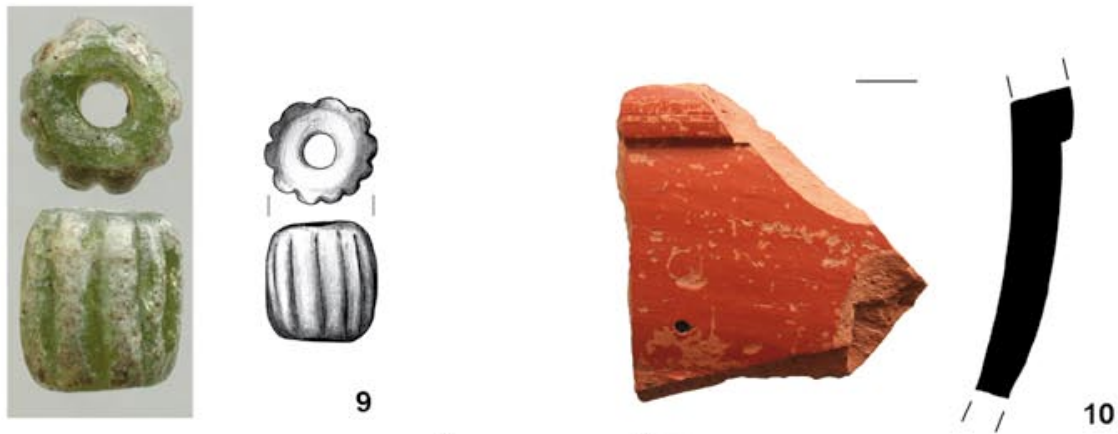

0 $3 \mathrm{~cm}$

Fig. 6. Jewellery, parts of clothing and garment accessories . 1-6: bronze, 7: bone, 8-9: glas, 10: pottery (drawing N. Lenkow, photo P. Dulęba) 

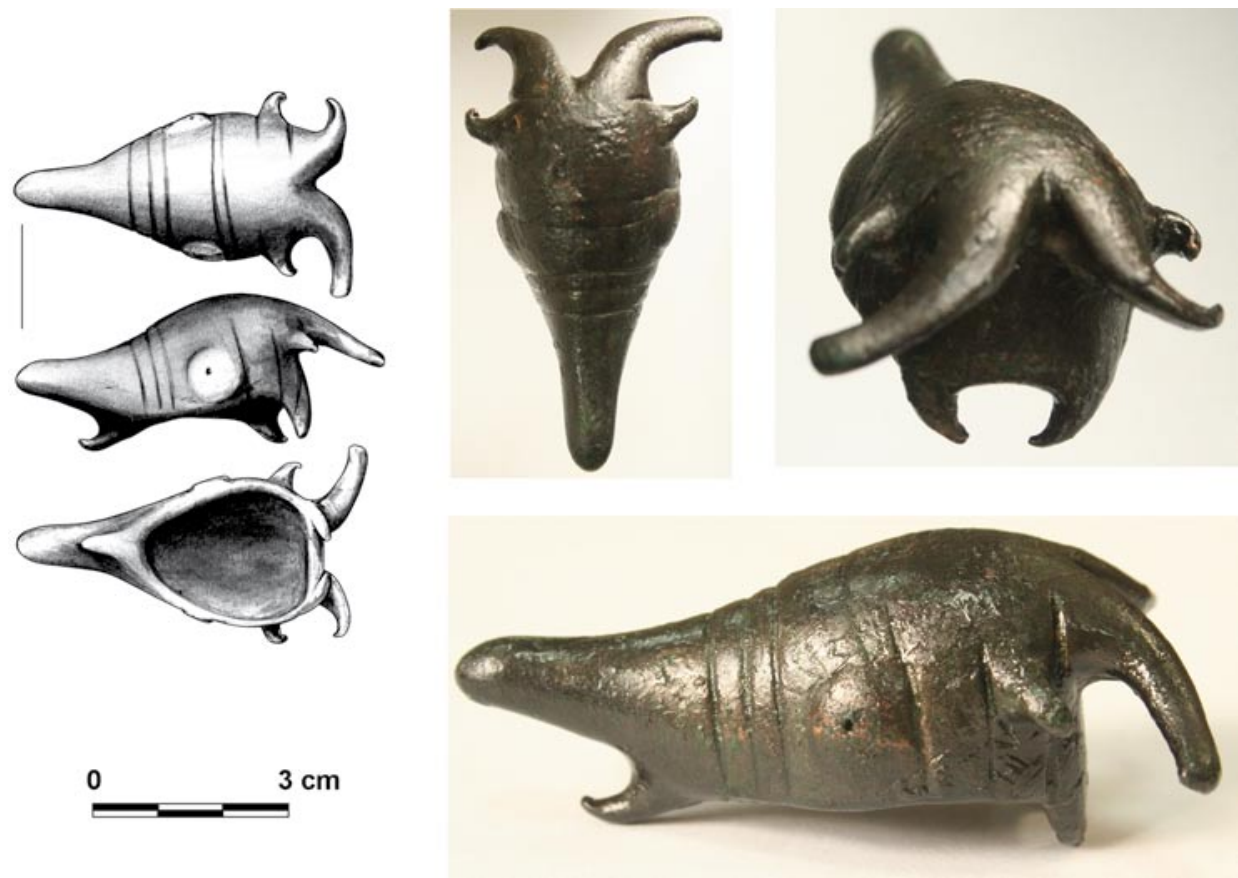

Fig. 7. Figurine of bronze

(drawing N. Lenkow, photo P. Dulęba) 

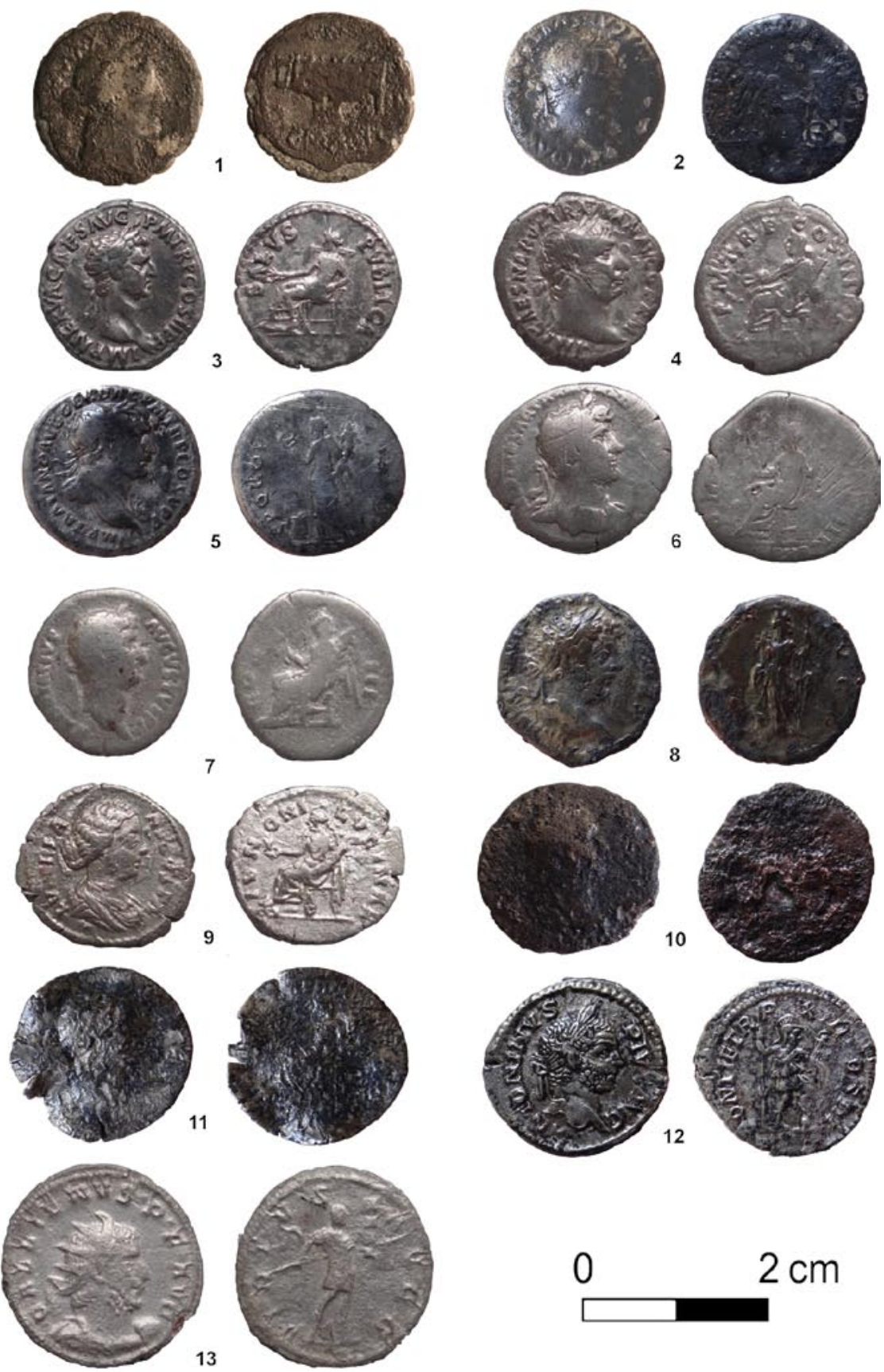

$2 \mathrm{~cm}$

Fig. 8. Roman coins: 1-13: silver

(photo P. Dulęba, P. Wysocki) 


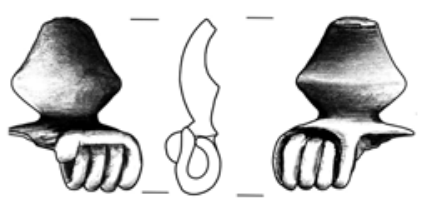

1

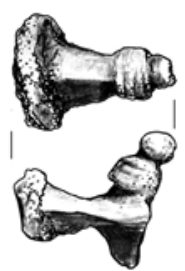

3

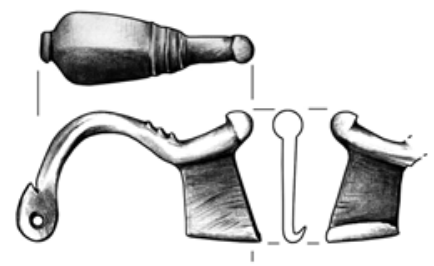

6

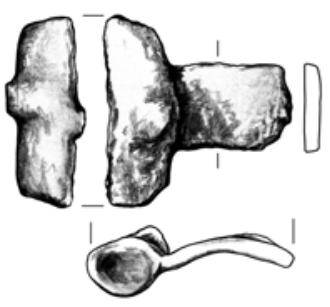

2

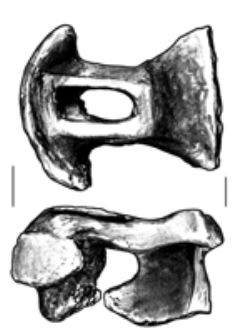

5

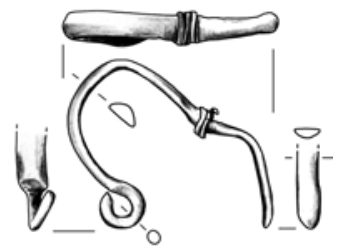

8

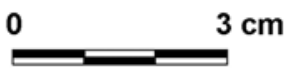

Fig. 4. Fibulae from Roman period. 1-8: bronze (drawing N. Lenkow)

7. Bronze fibula, partially preserved (part of the catch, the pin and the spring missing), length 2,9 cm, width 2,9 cm; type A 43; (Fig. 4:3).

8. Fibula made of bronze (bow) and iron (partially preserved pin and rests of the spring), quadrangular opening in the bow, head decorated with a gold plate, length $2,8 \mathrm{~cm}$, width 2,8 cm; type A 129; (Fig. 4:5).

9. Bronze fibula, partially preserved (pin and spring missing), bow triangular in crosssection, decorated with a plate, length $4,5 \mathrm{~cm}$, bow width 0,9 cm; type A 84; (Fig. 5:2).

10. Bronze, dove-shaped fibula, partially preserved (pin and bird head missing), decorated with incised ornament, hinge catching system, length $2,8 \mathrm{~cm}$, width $1,6 \mathrm{~cm}$; provincial Roman fibula, a so-called Taubenfibel; (Fig. 5:1). 
11. Bronze fibula, partially preserved (pin and spring missing), wide bow - triangular in cross-section, high catch-plate, length $3,4 \mathrm{~cm}$, bow width $1,1 \mathrm{~cm}$; group VII according to O. Almgren; (Fig. 4:6).

12. Fragment of a bronze fibula, preserved parts: wide bow - triangular in cross-section and part of a multi-coiled spring, length $2,9 \mathrm{~cm}$, width $1,1 \mathrm{~cm}$; group VII according to O. Almgren; (Fig. 4:7).

13. Fragment of a bronze fibula, strongly misshapen, preserved parts: bow - semi-circular in cross section, part of foot (including a fragment attached to the bow) and spring, length of the preserved fragment 3,3 cm, bow width 0,4 cm; type A 158; (Fig 4:8).

14. Fragment of a bronze bracelet, triangular in cross-section, decorated with knobs and ribbed bands, significant traces of wear, length of the preserved fragment $2 \mathrm{~cm}$; (Fig. 6:6).

15. Bronze strap end, band-shaped, flat, two openings for fastening, beak-shaped end semi-circular in cross-section, item bent, length 5,6 cm, width 1,2 cm; (Fig. 6:2).

16. Bronze strap end, band-shaped, quadrangular in cross-section, decorated with ribs, both ends damaged, preserved rib for fastening and part of round ending, item bent, length 4,6 cm, width o,8 cm; (Fig. 6:1).

17. Bronze aglet consisting of four quadrangular plates, partially damaged, fastened with four rivets (three of them preserved), dimensions $1,7 \times 1,9 \mathrm{~cm}$, width $0,6 \mathrm{~cm}$; (Fig. 6:4).

18. Bronze belt link, circular in cross-section, at two points thinner (probably due to use-wear), diameter 2,4 cm; (Fig. 6:3).

19. Bone pin, partially preserved, profiled head, body circular in cross-section, length 8,4 cm, body diameter 0,5 cm; (Fig. 6:7).

20. Round bead of blue glass, decorated with flecks of white, milk glass, diameter $1,9 \mathrm{~cm}$, width 1,1 cm; (Fig. 6:8).

21. Cylindrical bead of light green glass, decorated with vertical ribs, dimensions $1,8 \mathrm{x}$ 1,6 cm; (Fig. 6:5).

22. Bronze rivet, hemispherical head, bent shaft semi-circular in cross-section, head diameter 1,7 cm, length 2,1 cm; (Fig. 6:5).

23. Bronze figurine depicting a stylised goat head or head of a fantastic animal, hollow, decorated with relief and incised ornaments, dimensions 5,6 x 3,1 cm, width 2,4 cm; (Fig. 7).

\section{FIBULAE}

Surface surveys yielded 13 fibula specimens, which were found - as all of the items discussed in the paper - on the surface, in the modern topsoil layer. Fibulae are the most popular and most frequently recorded garment accessories at the sites associated with Przeworsk culture. This is mostly due to the fact that in the Roman Iron Age specimens made of non-ferrous metals prevailed. These do not tend to be severely affected by corro- 
sion and are easier to find by means of metal detector survey. The vast majority of the Iron Age settlements in Poland are located on farmlands and an effective survey is therefore only possible with the use of the iron discrimination mode.

The chronology of the earliest phase of the Przeworsk settlement might be determined through three finds of fibulae. The first one is a small, bimetalic (bronze and iron) specimen (Fig. 3:1) of the J. Kostrzewski's type K (Kostrzewski 1919, 34, Fig. 21). This type is characteristic of the Germanic societies inhabiting the north European Barbaricum (Völlling 1994, 163-171, attachment 3) - including the Przeworsk culture groups. In the chronological system developed for this cultural entity it constitutes the major fibula form characteristic of the A2 phase of the Pre-Roman Iron Age (Dąbrowska 1988, 29, plate III:47). According to the newest, detailed typological analysis, the specimen from Czechy should be classified as the "south Scandinavian variant". The main distribution area of these items is southern Sweden (Bockius and Łuczkiewicz 2004, map 11, list 8B).

The second find was an interesting and extremely rare specimen among the late La Tène type fibulae - a hybrid of the Schüsselfibel type and the A 65 type (Fig. 3:2). A very accurate analogue of the find was found at the Tyniec group settlement and Podlęże, Wieliczka district (Woźniak 1990, 57, plate XXX:o). Both specimens shall be classified as the Mailhac variants of group 6 Schüsselfibel according to the very precise typology developed by H. Meller (2012, 83, plate 65:12). The Schüsselfibel, including the specimens of the Mailhac variant, were produced from a very characteristic alloy - the so-called "white metal" (Meller 2012, 91).

Both Schüsselfibeln and A 65 type fibulae were characteristic of stage LT D1b in the La Tène period chronology (Waldhauser 1983, 332-334, plate 1; Fischer 1988, 237; Gebhard 1991, 94-96, fig. 42). Stage LT D1b in the Przeworsk culture settlement area corresponds with the end of stage A2 and the transitional horizon between stages A2 and A3 (Dąbrowska 1988, 57-59).

A slightly later chronology might be suggested for the partially preserved fibula representing Kostrzewski's type O (Fig. 3:3). In T. Völling's classification it corresponds with variant A 2aI (Völling 1994, 222, fig. 35a, b). In Barbaricum the O-type (A2a) fibulae occur in graves dated to the beginning of the Roman Iron Age, which matches the datings of the finds from Roman march camps (Völling 1994, 224-226, chart 15). The O-type fibulae are interregional forms. They are recorded within the whole of the north European Barbaricum, as well as in the Alpine and Danubian provinces of the Roman Empire (Völling 1994, attachment 9). A large series has recently been found at the settlements associated with the Puchov culture (Pieta 2008, fig. 33:18-25).

Finds dated to early stages of the Roman Iron Age are much more numerous. The A 68 type fibulae, of which one specimen was recorded in Czechy (Fig. 4:1), seem to have been widely used in European Barbaricum and are characteristic of stage B1b (Liana 1970, 442). Numerous finds of these fibulae in well dated contexts were recorded in the Danubian provinces, so it was possible to establish that they were extensively used between ca 40-70 AD (Kossack 1962). 
The next specimen found during the survey belongs to the popular group of the eye fibulae, and specifically to the so called Prussian series (A 57 - A 61) (Fig. 4:2). According to T. Liana's system of relative chronology developed for the Przeworsk culture, such fibulae are characteristic of stage B2a (Liana 1970, 442). The eye fibulae belonging to the Prussian series have frequently been recorded in the whole area settled by the Przeworsk culture societies with a concentration in northern and eastern Masovia (Andrzejowski 2001, 61, fig. 2).

The precise typological analysis of another Roman Iron Age fibula fragment recorded at the site was not possible due to its poor state of preservation (Fig. 4:3). It might probably be identified either as type A 80 - which is one of the variants of the so-called late strongly profiled fibulae - or a form belonging to series 5 , group V according to O. Almgren's classification. Both groups were relatively popular in the Przeworsk culture environment and are usually dated to the B2 stage of the Roman Iron Age and the transitional B2/C1 horizon (Godłowski 1970, 15, 21).

The site also yielded a bronze specimen of an A 84 type fibula (Fig. 5:2). Type A 84 fibulae were most probably manufactured in the northern part of the Roman province of Pannonia and occur relatively often at the sites located in the Vistula River basin (Dąbrowska 1994, 14-17, fig. 6). Their dating might be limited to the B2b-B2/C1 stages (Dąbrowska 1994, 19).

Another fibula in the assemblage represents the A 43 type (Fig. 4:4), which seems to have been very characteristic of the Przeworsk culture zone. The type has also been recorded in the middle Danube area (Olędzki 1998, fig. 19). The A 43 fibulae occurred occasionally in assemblages dated to late B2 stage but were mainly in use in the B2/C1 stage (Godłowski 1970, 15-16, plate I:52; Olędzki 1998, 82).

A very characteristic fibula of the A 129 type (Fig. 4:5) is also typical of the B2/C1 stage of the Roman Iron Age (Godłowski 1970, 15-16, fig. I:47). It has mostly been recorded in the Przeworsk culture zone and - until recently - only exceptionally found elsewhere, chiefly in the middle Danube and Tisza regions (Olędzki 1996, fig. 4; Machajewski 1998, 189). Latest research, however, revealed two new specimens from Lesser Poland (Naglik 2001, 32; Byrska-Fudali and Przybyła 2012, 532, fig. 27:4) and fourteen further finds from ten settlement sites in Moravia (Čižmář et. al 2009, 150, fig. 9:1-7), Lower Austria (Tejral 2006, fig. 22:4-5, 7-8, 10) and Bohemia (Droberjar 2015, ryc. 11:7; Jilek 2015, ryc. 186). The A 129 type fibulae have also been recorded at the site of Mušov-Hradisko, which was part of an extensive zone of dense settlement, where Roman march camps from the period of the Marcomannic Wars were located. They were also found in the Roman camp in Iža on Danube (Tejral 2006, 149, fig. 19:6).

The find of a zoomorphic, dove-shaped fibula with hinge construction (Fig. 5:1) is very unique. Zoomorphic fibulae with hinges are typically found in the former Roman provinces. Many of them were additionally decorated with enamel in a variety colours, especially in the western part of the Empire - in Gaul and Britain. The find from Czechy does not bear any traces of enamel and shall therefore rather be associated with similar finds 
from the Danubian provinces. Analogous dove-shaped specimens were found in Roman camps in Saalburg and Zugmantel in Hessen (Böhme 1972, 67, plate 27:1046-1048). Similar forms have also been recorded in Dacia, where they seem to have been in use throughout the whole 2nd century AD (Cociş 2004, 118-119, plate CII:1437-1442). However, in some of the Roman Provinces (Italia, Dalmatia, Raetia, Noricum) zoomorphic fibulae of similar shape and with a similar catch system were in use even in the 5 th and 6 th centuries (Martin 1994, 569, fig. 162:1-3). The find from Czechy is therefore difficult to date but, considering its context, it seems most probable its chronology corresponds with the dating of other Roman imports found at the site, that is the final stage of the Early Roman Iron Age and the beginning of the Late Roman Iron Age.

The survey discussed in this paper yielded also two unique bronze fibulae, which do not have accurate matches in O. Almgren's typology. However, details of their construction indicate that they might be associated with group VII, where specimens with high catchplate belong (Fig. 4:6-7). K. Godłowski, who analysed similar finds recorded in Upper Silesia, argued that they had mostly been in use during stages $\mathrm{B}_{2} / \mathrm{C}_{1}, \mathrm{C} 1 \mathrm{a}$ and $\mathrm{C} 1 \mathrm{~b}-$ as the other fibulae from group VII (Godłowski 1977, 23-24, plate XXIV:2, 5-6). Analogous specimens from the burial site in Drochlin, Włoszczowa district were dated to stage C1b (Kaczanowski 1987, 60, plate XXIV:4-6).

The youngest of the fibulae recorded in Czechy represented the A 158 type (Fig. 4:8), which is the most common form found at the late Roman Iron Age sites associated with the Przeworsk culture. Unfortunately, most of these fibulae - with the exception of some specific, ornamented ones - have a very long chronology. They seem to have circulated throughout the whole late Roman Iron Age and the beginning of the Migration Period (Godłowski 1970, 17-27; Godłowski 1977, 26-27).

\section{BRACELET}

A very interesting find in the context discussed in this paper was a small fragment of a bracelet (Fig. 6:6). It belongs to the group classified in the literature as the Simleul Silvaniei type (Rustoiu 1991; 1992). Bronze bracelets of this type are featured with a unique form of ornamentation along the circumference, that is three ribbed cords with three openwork rings and knobs (Rudnicki and Miłek 2011, figs. 3-4). The specimen from Czechy, although only fragmentarily preserved and heavily damaged by intensive use, shows clear parallels to the already mentioned pieces of jewellery.

The Şimleul Silvaniei type bracelets have been considered characteristic of the Dacian culture, since the finds are clearly concentrated in Transylvania and in the Carpathian Basin. However, a significant number of these bracelets have also been recorded within the Germanic settlement zone and at La Tène culture sites (Rudnicki and Miłek 2011, fig. 2). In terms of style the Țimleul Silvaniei type bracelets are very close to bracelets characteristic of 
the Celtic metalworking tradition and popular in the La Tène environment. Therefore they might barely be treated indicators of ethnicity (Rudnicki 2012, 474-475). Analogous decoration might be found on a whole variety of round Celtic pieces of jewellery known in the literature as knobbed rings (Knotenringen). The Şimleul Silvaniei bracelets do not have a precise chronology, as most of the specimens do not come from closed assemblages. Some of the finds from eastern Germany and Poland occurred in graves dated from phase A3 of the Pre-Roman Iron Age to phase B1 of the Roman Iron Age (Rudnicki and Miłek 2011, 125-132).

\section{BELT PIECES}

Metal belt pieces are well suited to serve as dating items in analytical studies and the survey yielded four pieces of belts. The bronze strap end with a poorly preserved ring (Fig. 6:1), which might be classified as type 5 according to the typology developed by R. Madyda-Legutko (2011, 48-55), is of greatest significance. Longer and narrower specimens of this type - classified as variant 1 - are typical of stage C1a of the late Roman Iron Age (Godłowski 1970, plate II:16; Madyda-Legutko 2011, 50). The state of preservation of the second strap end recorded at the site is definitely better (Fig. 6:3). However, it is a anique specimen, which might only be stylistically associated with similar items from the late Roman Iron Age and early Migration Period. The only analogue - although a distant one - is the item deposited in the inhumation burial in Kleinlangheim (Elbe region), which was dated to the transitional $\mathrm{C}_{3} / \mathrm{D}$ horizon (Tejral 1992, fig. 1:18).

The site in Czechy also yielded a small chain ring (Fig. 6:3) of bronze. At two points on the circumference it was significantly thinner, which most probably happened due to intensive use. Such items were parts of the so called belt links (Madyda-Legutko 2011, plate XLIII:1-2). Belt links occurred almost exclusively in Masovia, where they were mostly found in graves dated to phase B2 (Andrzejowski 2001, 74-75, fig. 17). The find is a very culturally specific sort of accessory and might undoubtedly serve as an ethnic indicator. Therefore, the find from Czechy - given that its interpretation is correct - might constitute an interesting testimony of the contacts between the particular regional groups of the Przeworsk culture.

Another belt fitting recorded in Czechy was a bronze aglet consisting of four quadrangular plates, partially damaged, originally fastened with four rivets (Fig. 6:4). Similar

aglets were found e. g. in the B2 inhumation burial from Marzęcin, Pińczów district, where a complete set of metal belt fittings was preserved (Kaczanowski and Poleski 1990, 287, fig. 2:7). 


\section{JEWELLERY AND OTHER ACCESSORIES}

Two specimens of glass beads represent another category of Roman imports recorded at the site. The first one, cylindrical in shape and decorated with ribs, was made of light green glass. It might be classified as belonging to group XVII (Fig. 6:9) according to M. Mączyńska's typology (Mączyńska 1977). The second one is round, made of cobalthued glass. Flecks of white milk glass were composed into its body (Fig. 6:8). It represents group XX according to Mączyńska. Glass beads from the Roman Iron Age were not chronologically sensitive. A general study of female burials from the Barbaricum area suggests that the influx of these pieces of jewellery increased during stage B2/C1 and was maintained in the subsequent period (Mączyńska 1977, 68).

Another piece of female attire recorded in Czechy was a bone pin (Fig. 6:7). The recently developed typology of these items does not include an exact analogue but it might be classified as belonging to group VIII, where types with strongly profiled heads belong. They are generally dated to the early Roman Iron Age (Dulkiewicz 2009, 230-232, chart 1). In contrast with metal pins, bone pins from the Roman Iron Age are not so frequently recorded. One of the explanations might be that they are not likely to survive cremation. The newest investigations, however, have provided some new sources. The excavations in Domasław, Wrocław district, yielded 23 specimens of bone pins (Żygadło et al. 2012, 505, fig. 25). Przeworsk settlements in Lesser Poland also produced such items - e. g. KrakówMogiła, Jakuszowice (Dulkiewicz 2009, fig. 1), Dalewice, Proszowice district (unpublished excavations by J. Gromnicki, finds from the collection of the Institute of Archaeology and Ethnology of the Polish Academy of Sciences, the Igołomia workshop) and Zagórzyce, Kazimierza Wielka district (Grygiel et al. 2009, 237, fig. 23:4-6).

The bronze rivet with a hemispherical head was most probably part of a casket (Fig. 6:5). Analogous rivets fastened bronze caskets mounts recorded in rich burials at the cemeteries in Chmielów Piaskowy, Ostrowiec Świętokrzyski district (Godłowski, Wichman 1998, 35-37, plate LXI-LXIV), and Opatów, Kłobuck district (Zagórska-Telega 2000, 314, fig. 5:9). The former grave yielded more than 40 bronze rivets, which resembled the specimen from Czechy in terms of shape and size. The caskets were in most cases deposited in female burials.

\section{FIGURINE}

The find of a bronze figurine depicting a stylised goat head or a fantastic animal resembling a goat (Fig. 7) stresses the significance of the site at the end of the La Tène period. Although the item appeared massive, it was hollow inside. It had two specifically formed catches indicating that it might have been a decorative element of a larger item, possibly a metal vessel or a lavishly decorated casket. Such examples of decorative art are hard to 
interpret, since parallel specimens are only occasionally recorded. Elementary stylistic features, however, indicate, that the find might be associated with zoomorphic decorations characteristic of the late La Tène period (e. g. Van Endert 1991, chart 9-10; Pieta 2008, phot. 30:2; Beneš 2015, fig. 5). Bronze goat heads serving as decorative elements of metal vessels are known from Celtic sites in southern Britain (Megaw 1970, 161-162; fig. 275).

\section{POTTERY}

The surface surveys in Czechy yielded 119 Przeworsk culture pottery sherds. The set of vessel forms fully corresponds with the chronology of the site established on the basis of metal finds. Over a half of the sherds might be dated to the Pre-Roman Iron Age (Fig. 9).
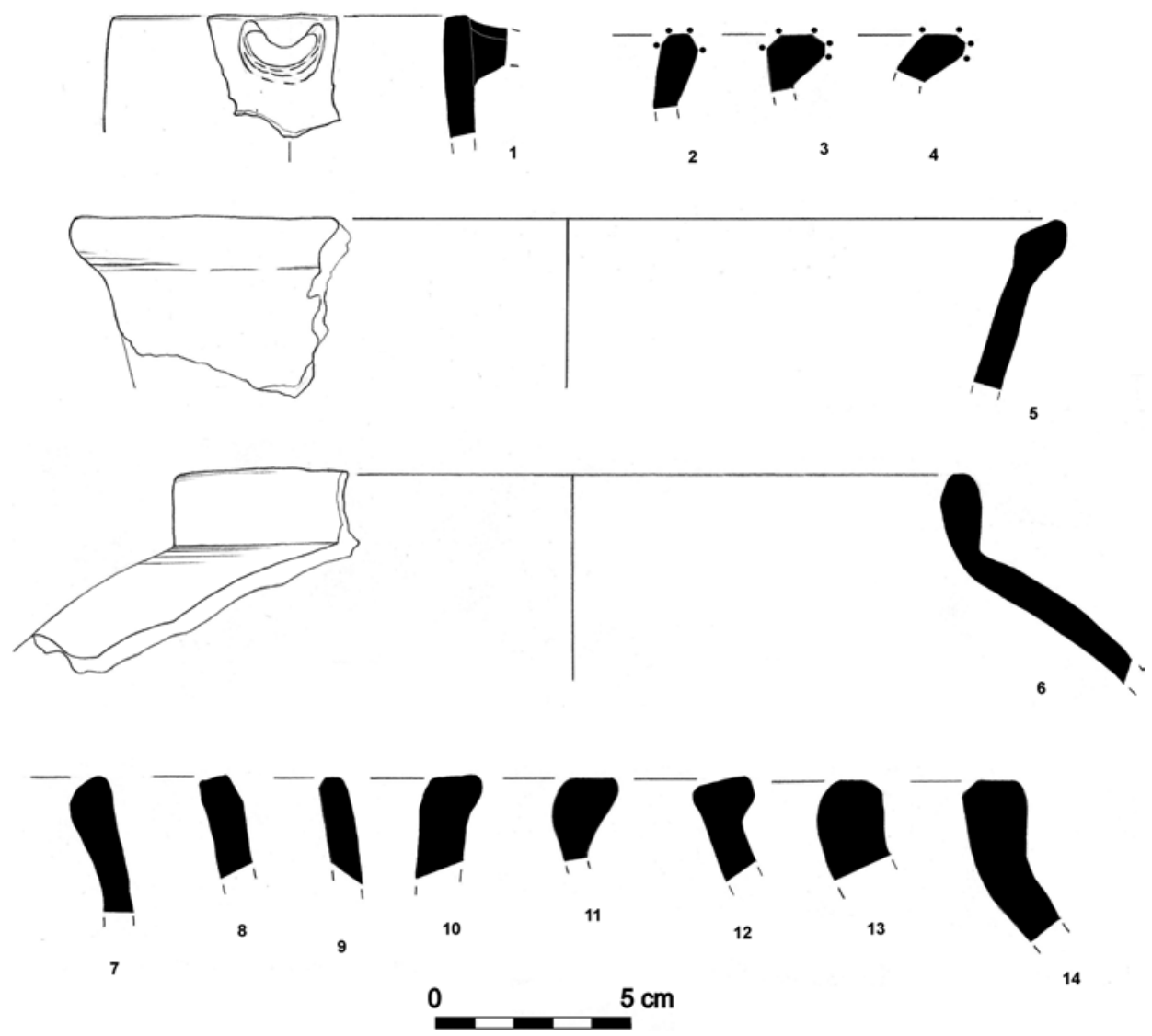

Fig. 9. Handmade vessels from the Younger Pre Roman period (drawing P. Dulęba) 
New data regarding the question of interregional contacts in the Iron Age...

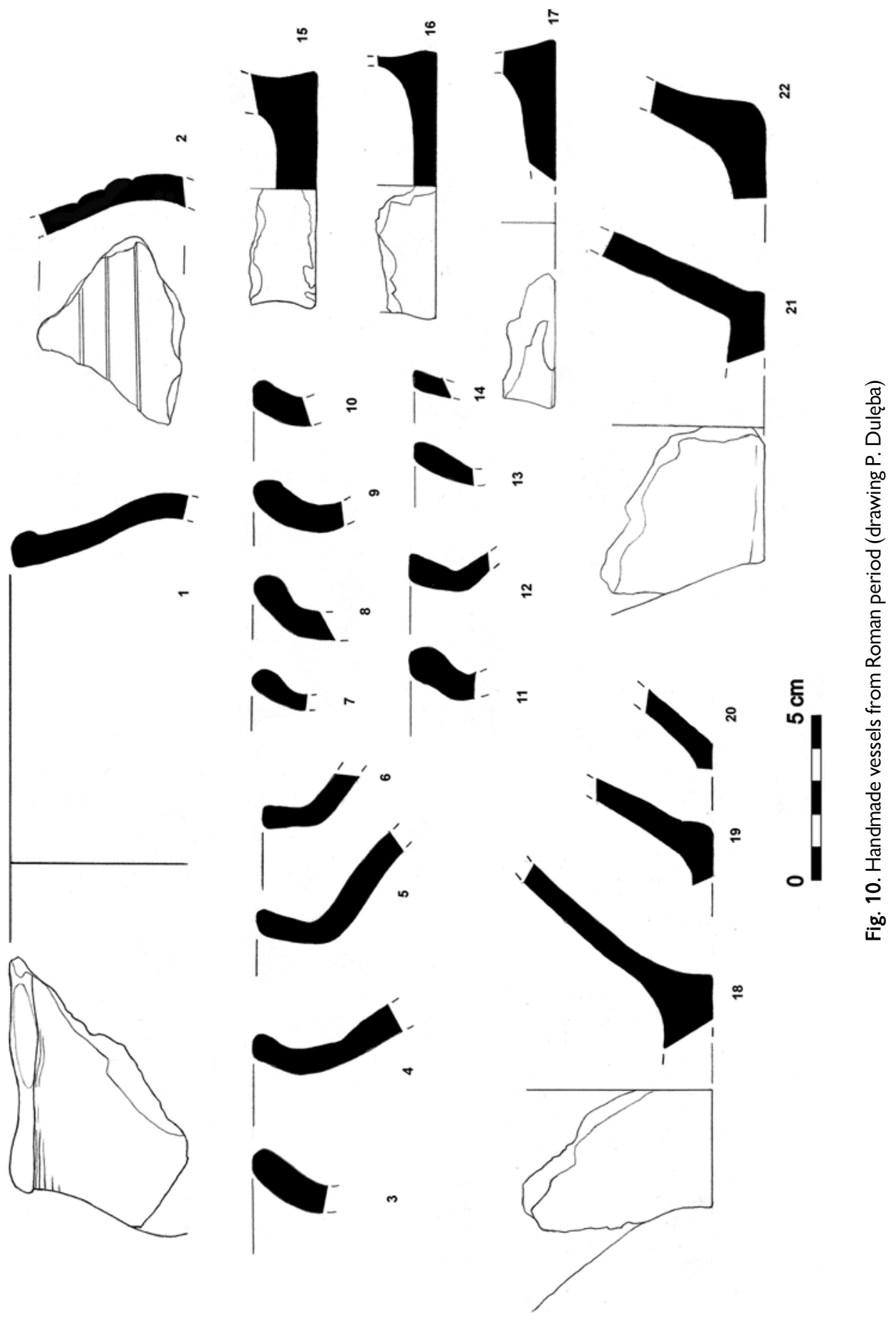



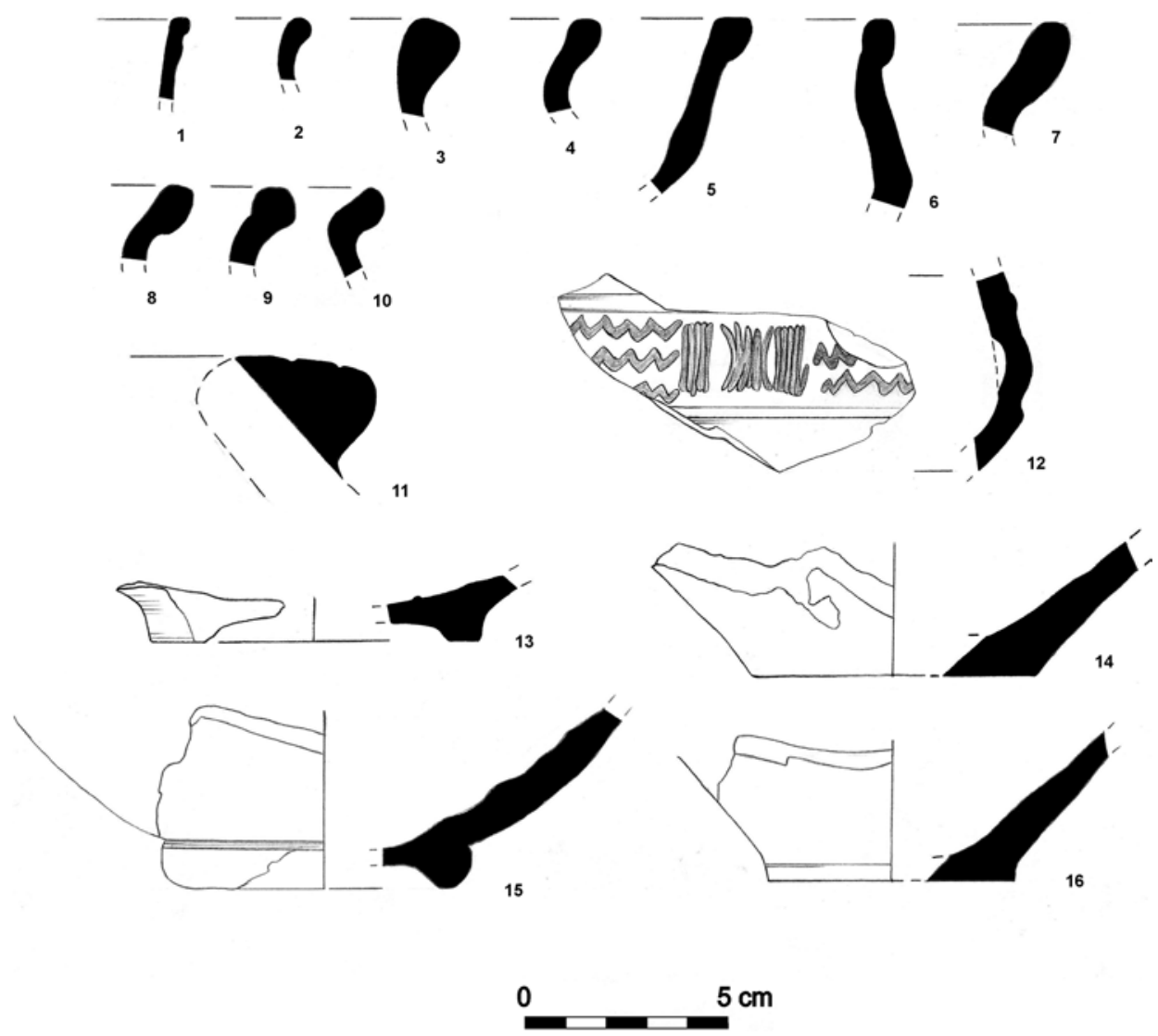

Fig. 11. Wheel-thurned vessels from Roman period (drawing P. Dulęba)

No vessel types representing only the so called older ceramic style were recorded. Most of the earliest forms might be roughly dated to phase A2 and A3, which is indicated e. g. by specimens with lightly facetted rims (Fig. 9:2-4) and a characteristic pot with a bulging body and cylindrical, straight rim (Fig. 9:6). Apart from grave contexts (Dąbrowska 1997, plate LXXIX:8, XCVIII:10, CXXXIX:14, CXLVI:3, CLXVII:10) this form occurs quite often at Tyniec group settlements (Poleska 2006, 103-104, fig. 16:3). A similar dating might be established for the rim of a cup (Fig. 9:1), which finds parallels in the A3 phase burials (Czarnecka 2007, plate CXXXIII:6, CXXXV:10).

Thirty pottery sherds represent the technological features characteristic of the so called blackened ware, which is the most frequently recorded type of Przeworsk culture pottery. The vessels were hand-built of a clay body containing mineral temper or - in much fewer cases - small amounts of fine temper made of crushed sherds. Both the inner and outer surface were carefully smoothened, polished and sometimes covered with a layer of graphite. 
Most of them might be dated to the early Roman Iron Age but some specific forms of vases and footed bowls (Fig. 10:15-17) are characteristic of phase B2 (Liana 1970, 439, plate V).

Thirty-nine fragments of wheel-made vessels were classified as workshop pottery (Fig. 11). Among them sherds belonging to the two basic technological groups (smooth and rough pottery - compare Dobrzańska 1980, 92-93) were identified, as well as very characteristic storage vessels - the Krausengefässe (Fig. 11:11). Well dated evidence for the workshop-type production was recorded in Zofipole, Cracow district, where a bronze fibula of the A 162 type was found with the ceramic material (Dobrzańska 2008, 187-188, fig. 12a). Additionally, radiocarbon datings of burnt wood from the already mentioned assemblage gave a result of 202-244 AD (Dobrzańska 2008, 188). Thus, the workshop pottery from Czechy should most probably be associated with the whole late Roman Iron Age period and early phase of the Migration Period.

The site in Czechy yielded also a Roman Samian ware fragment. Unfortunately, its poor state of preservation does not allow typological classification (Fig. 6:10). Samian ware sherds are relatively frequently found in western Lesser Poland. Before the specimen from Czechy was recorded, Samian ware sherds within the micro-region of the Szreniawa River and its minor tributary - Ścieklec had been found at the settlements in Bobin, Dalewice, Mysławczyce and Opatkowice, Proszowice district (Tabula Imperii Romani, M 34 - Kraków 2002, map D).

\section{NUMISMATIC SOURCES}

1. C. Marius Capito ( $81 \mathrm{BC}$ ), denarius serratus, Rome $81 \mathrm{BC}$, diam. 18-18,5 mm, weight 3,49 g, Crawf.: 378/1c, Syd.: 744b.

Obv. CAPIT and numeral

Ceres head right.

Rev. Numeral and in line: C.MARI.C.F, below S.C

Ploughman with a yoke and a pair of oxen right.

(Fig. 8:1)

2. Titus (79-81 AD), denarius, Rome $79 \mathrm{AD}$, diameter 17,1-17,9 mm, weight 2,84 g, RIC II 6.

Obv. IMP TITVS CAES VESPASIAN AVG P M

Laureate head of emperor right.

Rev. TR P VIIII IMP XIIII COS VII P P

Quadriga carrying corn-ears advancing left.

(Fig. 8:2) 
3. Nerva (96-98 AD), denarius, Rome 96 AD, diam. 17,1-18,6 mm, weight 3,21 g, RIC II 9, ERIC 16.

Obv. IMP NERVA CAES AVG PM TR P COS II PP

Laureate head of emperor looking right.

Rev. SALVS PVBLICA

Salus seated left with ears of corn in her hand.

(Fig. 8:3)

4. Trajan (98-117 AD), denarius, Rome $100 \mathrm{AD}$, diam. 18,7-19,4 mm, weight 3,02 g, RIC II 40, ERIC 31.

Obv. IMP CAES NERVA TRAIAN AVG GERM

Laureate head of emperor right.

Rev. PM TR P COS III PP

Vesta seated left holding patera and torch.

(Fig. 8:4)

5. Trajan (98-117 AD), denarius, Rome 103-104 AD, diam. 17,9-18,2 mm, weight 2,81 g, RIC II 175.

Obv. IMP TRAIANO AVG GER DAC PM TR P COS V PP

Laureate bust of emperor looking right.

Rev. SPQR OPTIMO PRINCIPI

Felicitas standing left holding caduceus and cornucopia; small altar at her feet to the left.

(Fig. 8:5)

6. Hadrian (117-138 AD), denarius, Rome 119-122 r., diam. 17,9-20 mm, weight 3,oo g, RIC II 127d, ERIC 170.

Obv. IMP CAESAR TRAIAN HADR(IANVS AVG (?))

Laureate, draped and cuirassed bust of emperor.

Rev. PM [TR P (?)] COS III, LIB PVB (in line)

Libertas seated left holding branch and sceptre.

(Fig. 8:6)

7. Hadrian (117-138 AD), denarius, Rome 136-138 AD, diam. 17,4-18,2 mm, weight. 2,09 g, RIC II 345, ERIC 171.

Obv. HADRIANVS AVGVSTVS PP

Laureate head of emperor looking right.

Rev. COS III

Victory seated left, holding wreath and palm.

(Fig. 8:7) 
8. Marcus Aurelius/Lucius Verus (161-180 AD), denarius, Rome 161-180 r., diam. 1717,6 mm, weight. 2,15 g, RIC III (M. Aurelius).

Obv. Laureate head of emperor looking right.

Rev. Figure standing left, holding spear or sceptre.

Remarks: The obverse side was struck with a very worn stamp, the legend is "blurred", illegible. The reverse side was not properly cleaned and covered with copper compounds from the alloy - precise identification impossible.

(Fig. 8:8)

9. Marcus Aurelius (161-180 AD), denarius, Rome 163-169 AD, diam. 17,3-19,1 mm, weight 3,30 g, RIC II 770, ERIC 6.

Obv. LVCILLA AVGVSTA

Bust right.

Rev. IVNONI LVCINAE

Juno seated left, holding flowers and infant.

(Fig. 8:9)

10. 2nd century BC, denarius, diam. 17,8-19 mm, weight 2,11 g.

Obv. Laureate (?) head or bust of emperor looking right.

Rev. (?)

Remarks: Heavily corroded fourrée, most probably from the 2nd century BC. State of preservation makes it impossible to even determine the issuer.

(Fig. 8:10)

11. 2nd century BC, denarius, diam. 18,9-19,4 mm, weight 2,35 g.

Obv. Head of emperor looking right.

Rev. (?)

Remarks: Coin heavily damaged already in antiquity. On the surface traces of striking with a sharp, hard tool. Legend and depictions illegible.

(Fig. 8:11)

12. Caracalla (197-217 AD), denarius, Rome $210 \mathrm{AD}$, diam. 18,5-19,5 mm, weight 2,65 g, RIC IV 117a.

Obv. ANTONINVS PIVS AVG

Laureate head of emperor looking right.

Rev. PONTIF TR P XIII COS III

Virtus standing right, holding spear, left foot on helmet.

(Fig. 8:12) 
13. Gallienus (VIII 260-268 AD), antoninianus, Lugdunum 258-259 AD, diam. 21,221,8 mm, weight 2,89 g, RIC V 58, ERIC 132.

Obv. GALLIENVS P F AVG

Cuirassed and radiated bust of emperor.

Rev. VIRTVS AVG

Figure of Gallienus standing right, holding spear and banner.

(Fig. 8:13)

The composition of the assemblage of Roman coins from site 17 in Czechy reflects very well the general proportions between the finds of particular coin issues recorded in Poland to date. These proportions are similar both for the amateur finds and finds from regular investigations of the settlements sites (Dymowski 2011, 17; Micyk 2007, 33-34), also those with long chronology testified by large series of dating artefacts and coins (Bursche et al. 2000, chart 1; Rudnicki 2006, 105-106). The significant number of coins dated to the 2nd century BC reflects the increased influx of Roman coins - especially denarii - to the Przeworsk culture environment rather than the dynamic deve-lopment of the settlement in Czechy in that period.

Special attention should be paid to the Republican denarius dated to $81 \mathrm{BC}$, which makes it the earliest coin recorded at the site so far. Its poor state of preservation indicates that it was in circulation for a long time. The coin is covered with a specific layer of hard oxides, which results from the influence of high temperatures (Fig. 8:1). In the general context of the Republican coin finds, which only constitute a fraction of a percent among the coins recorded at the Przeworsk culture settlements, the discussed specimen is definitely rare but not exceptional.

The next coin in chronological order is the denarius of Titus dated to $79 \mathrm{AD}$ (Fig. 8:2). Finds from that period are not frequently recorded in Poland. The specimen is heavily worn but, obviously, it might not be determined whether the wear occurred during its circulation time in the Barbaricum or if it arrived in this area later, already in poor condition.

As many as nine of the thirteen coin specimens recorded at the site were issued at the turn of the 1st and the 2nd century $\mathrm{AD}$ and in the first half of the latter. It was when the greatest increase in the Roman coin influx to the Przeworsk culture area occurred (Dymowski 2011, 17; Micyk 2007, 33-34). The Nerva denarius (Fig. 8:3) also belongs to this group. The Nerva coins are only seldom recorded in Poland and it seems it might be due to the short reign of this emperor, which resulted in modest minting activity and limited number of the issues available on the market. In this light, the very occurrence of the Nerva coins at the Przeworsk culture sites indicates that the end of his reign or the beginning of the reign of his successor saw an increase in the importance of coins in the exchange between the Empire and the Przeworsk culture societies. The coin discovered in Czechy is in good state of preservation and only by minor traces of wear were observed. 
This indicates that it had not been long in circulation before being deposited in the cultural layers at the site.

Other identifiable coins were issued by Trajan, Hadrian and Marcus Aurelius (Fig. 8:49) and belong to groups commonly recorded in the Przeworsk culture environment (Dymowski 2011, 17; Micyk 2007, 33-34). While the very poor state of preservation of the remaining specimens makes precise identification of the issuer impossible, the preserved fragments of depictions suggest the Roman Iron Age dating. Among these specimens a heavily corroded fourrée was identified. Its state of preservation, however, does not allow the identification of the issuer. The profile of the emperor on the obverse side seems to be very worn and the coin entirely lacks the silver layer, which suggests that it remained in circulation long after the forgery had become apparent - even at the first glance.

Another noteworthy find is a heavily damaged denarius, featured with traces of multiple strikes with a hard, sharp tool on both sides (Fig. 8:11). Accidental damages due to later agricultural activities must be definitely excluded. It is also highly improbable that someone deprived the coin of its value by damaging it, or that one of the inhabitants of the settlement purposely removed the depiction of the emperor. This example might indicate that for the societies inhabiting the Barbaricum it was not the "image" on the coin, which determined its value but rather the weight of the precious metal it contained.

The Caracalla denarius from the issue dated to $210 \mathrm{AD}$ (Fig. 8:12) comes from the period, when a clear decrease in the coin influx to the Przeworsk culture settlement area might be observed. It is exceptionally well preserved and the depictions barely have any traces of wear. This might indicate that it was deposited shortly (with a maximum limit of a couple of years) after it had been produced.

The chronologically youngest specimen in the assemblage discussed in this section is the antoninianus of Gallienus issued in 258-259 AD (Fig. 8:13). The date of the issue falls within the period of the significant decrease in the Roman coin influx to the Przeworsk culture areas, which was related to the gradual debasement of the Roman currency and shrinking silver content in coins. Nevertheless, the antoninianus recorded in Czechy contains a significant amount of silver and the image is relatively well preserved. In this case also the coin was probably deposited only a couple of years after being struck.

\section{SUMMARY - THE INTERREGIONAL CONTACTS}

Finds from Czechy clearly indicate that the settlement established during phase A2 of the Pre-Roman Iron Age existed all the way to the late Roman Iron Age and possibly to the early Migration period. It is worth mentioning that the surveys did not yield any finds of the La Tène type pottery dated to the middle La Tène period, which was frequently recorded at other places within the Szreniawa River valley (Dulęba 2009, fig. 1). This might 
obviously be due to the small scale of the investigations but the analysis of the metal items also indicates that the site was not inhabited by the Celts in phases LT B2b - LT C2.

The Celtic coin hoard accidentally found at the discussed site contained fourteen silver specimens of coins associated with the Eravisci tribe. In the vicinity of the hoard a nominally gold coin classified as a Cracovian type stater (Dulęba, Wysocki, in print) was recorded. Given the state of preservation and the weight of the Eravisci coins, it might be assumed that they most probably were imitations. The stater, however, was a local issue associated with the coinage of the Celtic tribe of Boii and related to the nearby Tyniec group settlement zone.

The deposition of the hoard might probably be dated to the end of the LT D2 phase, as indicated by the chronology of the circulation of the Eravisci coins and the Cracovian type stater (Dulęba and Wysocki, in print). The Celtic tribe of the Eravisci inhabited the present Budapest area (Bónis 1969, 223) until the Roman conquest. It is noteworthy that the hoard is the first hard evidence for strong ties between the Celtic Eravisci and the area north of the Carpathians. These contacts were previously anticipated on the basis of the similarities between pottery assemblages from the Tyniec group sites and the published materials from the Gellérthegy-Tabán oppidum - considered to be the capital of the Eravisci (compare Bónis 1969, Woźniak 1990).

The rare Mailhac variant fibula was not a surprising find in this context. Fibulae of this type were recorded almost exclusively in the Po valley and in Languedoc (Meller 2012, map 26). Two further specimens have recently been found at the oppidum of Trenčianske Bohuslavice in western Slovakia (Pieta 2008, 43, fig. 16:20, 22). This clearly indicates that the find from Czechy is yet another evidence for the intensive cultural contacts along the so- called "Amber Route", which went northwarths from the city of Aquileia in northern Italia (Fig. 12). The site in Czechy was most probably located on the eastern branch of the route running along the Vistula River valley and intensively used in the late La Tène period (Bochnak 2014, 192-193).

The rapid cultural changes which resulted in the disappearance of the Tyniec group settlements during stage B1a, did not break the links between western Lesser Poland and areas south of the Carpathians and Sudetes. These seem to have persisted during the early Roman Iron Age period. It seems that it was not the cultural and linguistic connection between the Celtic inhabitants of the Tyniec group settlements and the Celtic peoples of the Danubian provinces, which was the crucial factor in facilitating the trade exchange but rather the convenient geographic location. The Vistula River valley and the Kraków Gate macroregion offer the most accessible gateways to the east and northeast and have for centuries been used as communication routes.

Western Lesser Poland, and especially the loess uplands between the Dłubnia and Nida rivers, yielded substantial amounts of Roman coins. Most of them were recorded at settlement sites or as stray finds (Tabula Imperii Romani, M 34 - Kraków 2002, map C). The Szreniawa River valley is no exception and the site in Czechy is located in the very centre 


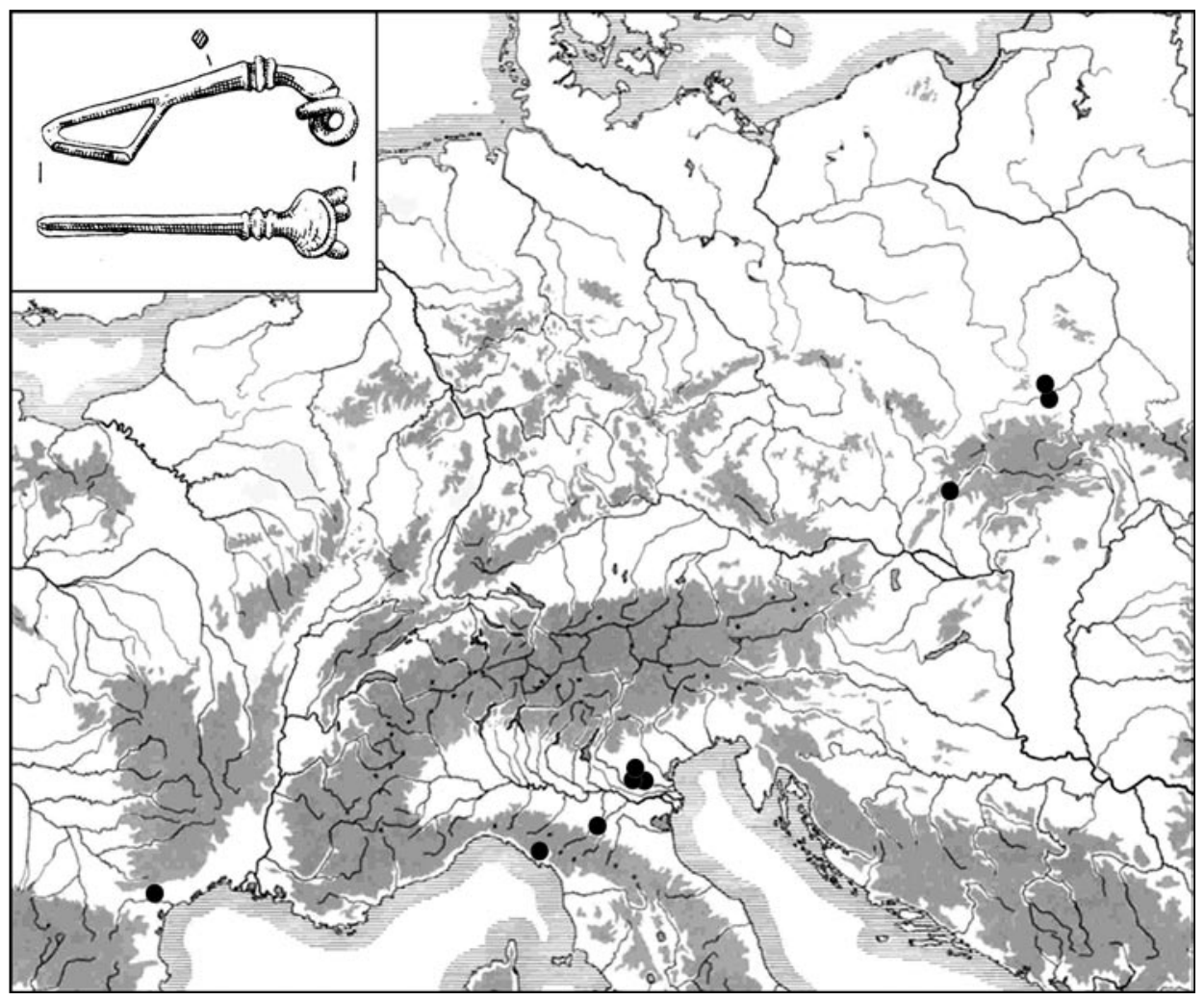

Fig. 12. Finds of Mailhac type of Late La Tène fibulae according Meller 2012 with later additions

of the area densely inhabited in the Roman Iron Age. In the light of this characteristics and the already mentioned new finds of the imported jewellery pieces and garment accessories, the vital interregional links seem to have been maintained for a relatively long time.

The already discussed finds of type A 43 (Olędzki 1998, fig. 19) and type A 129 fibulae (Fig. 13) from the middle Danube area are yet another piece of evidence for the existence of strong ties between this region and the Przeworsk culture zone. It might have been associated with a small scale migration towards the Roman Empire or intensive trade exchange along the "Amber Route". The route connected the Roman provinces (mainly Noricum, Pannonia, Raetia) and the areas inhabited by the superiores barbarii mentioned in the written sources (Scriptores Historiae Augustae, Vita Marci 14) and identified with the Przeworsk culture societies.

Moravia was a very important strategic point on the north - south route. The new finds of garment accessories, which used to be treated as "ethnic indicators" of the Germanic Przeworsk culture peoples, might therefore be interpreted in two ways. They might consti- 


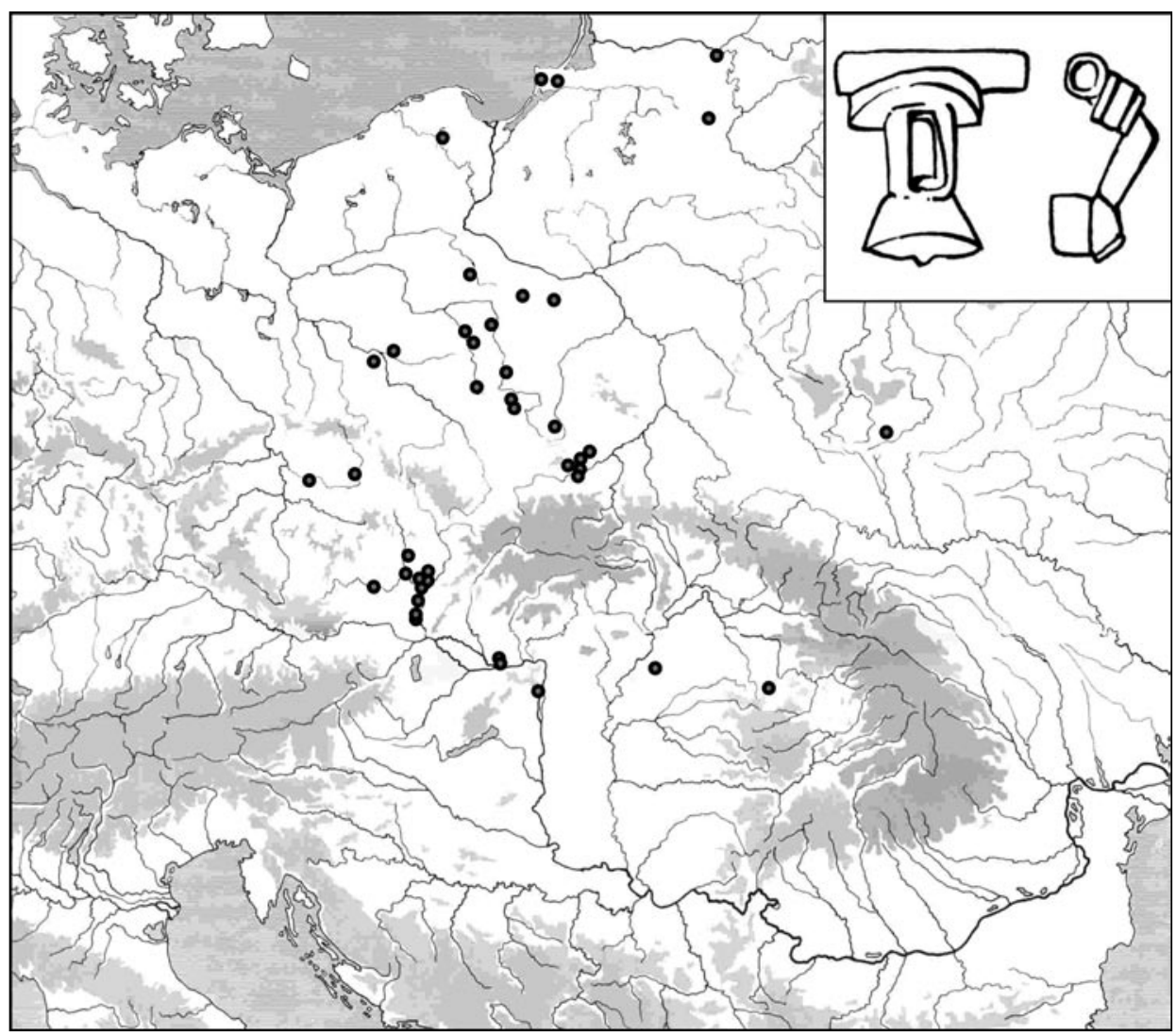

Fig. 13. Finds of A 129 type fibulae according Olędzki 1996; Olędzki 1998; Čižmář et al. 2009 with later additions

tute evidence for small scale migration into the Roman Empire undertaken e. g. by mercenaries, merchants or diplomats. On the other hand, it might be argued that those metal garment accessories did not in fact serve as ethnic indicators but were used in different regions by different ethnic groups. Therefore they might have made their way to the south by means of trade exchange.

The finds from Czechy indicate that the most intensive contacts with the areas south of the Carpathians should be dated to the end of the La Tène period and the turn of the early and late Roman Iron Age. This might be quite straightforwardly associated with periods of settlement stability observed at the Przeworsk culture sites in western Lesser Poland (Godłowski 1985, 39, 61, 79).

Detailed analysis of the finds of Roman imports at the Przeworsk culture settlement sites is a matter of greatest importance here. Cemeteries and grave assemblages have pur- 
posely been left out in this paper, as they by their nature constitute a very specific category of archaeological sources. Since the prevailing burial custom usually determines which categories of items are deposited in graves, the other categories are poorly represented or not represented at all (the so-called "dead culture" phenomenon). This process and the cognitive limitations it poses were thoroughly discussed already by H. J. Eggers (1959). Considering these limitations, it might be argued that settlement sites are the best indicators of the intensity of cultural contacts. Although the composition of the find assemblages might at first seem haphazard, it gives a more realistic idea of what the proportions between the particular categories of items used by the inhabitants of the site might have been.

The studies of the Iron Age in Poland has until very recently focused on the typological and chronological analyses of the finds. Cemeteries constituted an overwhelming majority of the investigated sites, as they were especially suitable for that purpose. The last two decades saw a great increase in the number of large surface settlement excavations. While the investigations made enormous amounts of data available for the studies of the Roman Iron Age, these are in many cases difficult to date on the basis of the previously developed typological and chronological systems. One of the major obstacles is the lack of metal finds which are the main category of dating artefacts in the Iron Age - and especially in the Roman Iron Age - archaeology. Detailed metal detector surveys on the accumulation layers are only exceptionally conducted during rescue excavations. In some cases - fortunately more and more isolated - metal detectors are not even used for the exploration of the feature fillings. This seems to be the main reason for the lack of metal finds, which are of crucial importance for establishing the time frames for the functioning of the particular sites. On the contrary, sites investigated exclusively by means of surface surveys yielded spectacular results (compare Dulęba 2014, 334-335).

The latest research clearly indicates that the number of Roman imports, especially from the Danubian provinces, was unexpectedly high during the whole period of the existence of the Przeworsk culture. Even the items from accumulation layers, apparently of little importance, indicate that it was a mass scale phenomenon.

\section{References}

Andrzejowski J. 2001. Wschodnia strefa kultury przeworskiej - próba definicji. Wiadomości Archeologiczne 54 (1995-1998), 59-87.

Beneš Z. 2015. Záchranný archeologický výzkum podhradí hradiště Kolo u Týnce nad Labem, okr. Kolín. Předběžná zpráva. Archeologie ve Střednich Čechách 19(1), 245-253.

Bochnak T. 2014. Importy celtyckie $w$ kulturze przeworskiej i oksywskiej na ziemiach polskich $w$ młodszym okresie przedrzymskim. Zróżnicowanie - drogi napływu - kontekst kulturowy. Rzeszów: Wydawnictwo Uniwersytetu Rzeszowskiego. 
Bockius R. and Łuczkiewicz P. 2004. Kelten und Germanen im 2-1. Jahrhundert vor Christus. Archäologische Bausteine zu einer historischen Frage (=Monographien Römisch-Germanischen Zentralmuseums 58). Mainz: Verlag des Römisch-Germanischen Zentralmuseums.

Böhme A. 1972. Die Fibeln der Kastelle Saalburg und Zugmantel, Saalburg Jahrbuch 29, 5-112.

Bónis É. B. 1969. Die spätkeltische Siedlung Gellérthegy-Tabán in Budapest, (=Archaeologia Hungariae 47). Budapest: Académiai Kiadó.

Bursche A., Kaczanowski P. and Rodzińska-Nowak J. 2000. Monety rzymskie z Jakuszowic. In R. Madyda-Legutko and T. Bochnak (eds.), Superiores Barbari. Księga pamiątkowa ku czci Profesora Kazimierza Godłowskiego. Kraków: Instytut Archeologii UJ, 101-130.

Byrska-Fudali M. and Przybyła M. M. 2012. Badania ratownicze na stanowisku 2 w Modlniczce, gm. Wielka Wieś. In S. Kadrow (ed.), Raport 2007-2008 1. Warszawa: Narodowy Instytut Dziedzictwa, 509-553.

Čižmář M., Čižmářová J., Kejzlar M. and Kolniková E. 2009. Detektorová prospekce archeologických lokalit na Moravě v roce 2008. Přehled Výzkumů 50, 139-152.

Cociş S. 2004. Fibulele din Dacia Romană / The Brooches from Roman Dacia (=Bibliotheca Ephemeris Napocensis 3). Cluj-Napoca: Editura Mega.

Czarnecka K. 2007. Oblin. Ein Gräberfeld der Przeworsk-Kultur in Südmasowien (=Monumenta Archaeologica Barbarica 13). Warszawa: Państwowe Muzeum Archeologiczne w Warszawie.

Dąbrowska T. 1988. Wczesne fazy kultury przeworskiej. Chronologia - zasięg - powiązania. Warszawa: Państwowe Muzeum Archeologiczne.

Dąbrowska T. 1994. Późne odmiany fibul silnie profilowanych w Polsce. Wiadomości Archeologiczne 53(1), 3-34.

Dąbrowska T. 1997. Kamieńczyk. Ein Gräberfeld der Przeworsk-Kultur in Ostmasowien (=Monumenta Archaeologica Barbarica 3). Kraków: Instytut Archeologii i Etnologii Polskiej Akademii Nauk, Państwowe Muzeum Archeologiczne w Warszawie.

Dobrzańska H. 1980. Zagadnienia datowania ceramiki toczonej w kulturze przeworskiej. Archeologia Polski 24, 87-152.

Dobrzańska H. 2008. Zagadnienie dużych ośrodków produkcji ceramiki szarej w środkowoeuropejskim Barbaricum: przypadek Zofipola k. Krakowa. In A. Błażejewski (ed.), Ceramika warsztatowa $w$ środkowoeuropejskim Barbaricum. Wrocław: Instytut Archeologii UWr, 175203.

Droberjar E. 2015. Markomannen und superiores barbari in Třebusice und Jevičko zur Zeit der Markomannenkriege. Zur Problematik der Übergangsstufe B2/C1 in Böhmen und Mähren. Přehled Výzkumů 56/2, 103-125.

Dulęba P. 2009. Przemiany kulturowe w Zachodniej Małopolsce w okresie od III do I wieku przed Chr. Przyczynek do kontaktów między Celtami a Germanami. In M. Karwowski and E. Droberjar (eds.), Archeologia Barbarzyńców 20o8. Powiązania i kontakty $w$ świecie barbarzyńskim (= Collectio Archaeologica Ressoviensis 13). Rzeszów: Instytut Archeologii Uniwersytetu Rzeszowskiego, 11-35. 
Dulęba P. 2014. Results of a surface survey carried out in Nieprowice, site 5, Pińczów district in 20072009. Sprawozdania Archeologiczne 66, 315-357.

Dulęba P. and Wysocki P. (in print). New discovery of Celtic coin hoard from the western Lesser Poland.

Dulkiewicz A. 2009. Szpile kościane i rogowe kultury przeworskiej na terenie Polski: typologia, chronologia i rozmieszczenie. Folia Praehistorica Posnaniensia 15, 209-235.

Dymowski A. 2011. Znaleziska monet rzymskich z terenu Polski rejestrowane $w$ pierwszych latach XXI wieku. Aspekty źródłoznawcze. Zielona Góra: Eternum.

Eggers H. J. 1959. Einführung in die Vorgeschichte, München: Piper \& Co Verlag.

Endert van D. 1991. Die Bronzefunde aus dem oppidum von Manching (=Ausgrabungen in Manching 13). Stuttgart: Franz Steiner Verlag.

Fischer F. 1988. Südwestdeutschland im letzten Jahrhundert vor Christi Geburt. Anmerkungen zum Forschungsstand der Spätlatènzeit. In D. Planck and A. Wais (eds.), Archäologie in Würtemberg. Stuttgart: Konrad Theiss, 235-250.

Gebhard R. 1991. Die Fibeln aus dem Oppidum von Manching (=Ausgrabungen in Manching 14). Stuttgart: Franz Steiner Verlag.

Godłowski K. 1970. The Chronology of the Late Roman and the Early Migration Periods in Central Europe (= Prace Archeologiczne 11). Kraków: Instytut Archeologii UJ.

Godłowski K. 1977. Materiały do poznania kultury przeworskiej na Górnym Śląsku (część II). Materiaty Starożytne i Wczesnośredniowieczne 4, 7-234.

Godłowski K. 1985. Przemiany kulturowe i osadnicze w południowej i środkowej Polsce w młodszym okresie przedrzymskimi iw okresie rzymskim (= Prace Komisji Archeologicznej 23). Wrocław: Zakład Narodowy im. Ossolińskich - Wydawnictwo PAN.

Godłowski K. and Wichman T. 1998. Chmielów Piaskowy. Ein Gräberfeld der Przeworsk-Kultur im Świętokrzyskie-Gebirge (=Monumenta Archaeologica Barbarica 6). Kraków: Muzeum Archeologiczne w Krakowie.

Grygiel M., Pikulski J. and Trojan M. 2009. The research on the multicultural site no. 1 in Zagórzyce, com. and distr. Kazmierza Wielka, Świętokrzyskie voiv. during the years 2003 to 2004. Recherches Archéologiques NS 1, 199-275.

Jilek J. 2015. Doba řimská a doba stěhováni národů. In J. Jilek (ed.), Proti proudu času. Pardubicko $v$ pravěku a raném střdověku. Pardubice: Východočeské muzeum w Pardubicich.

Kaczanowski P. 1987. Drochlin. Ciałopalne cmentarzysko kultury przeworskiej z okresu wphywów rzymskich (= Prace Archeologiczne 40). Kraków: Instytut Archeologii Uniwersytetu Jagiellońskiego.

Kaczanowski P. and Poleski J. 1990. Materiały grobowe kultury przeworskiej z Marzęcina, woj. Kielce. Sprawozdania Archeologiczne 42, 281-292.

Kaczanowski P. and Margos U. (eds.). Tabula Imperii Romani, M 34 - Kraków 2002. Kraków: Polska Akademia Umiejętności.

Kossack G. 1962. Frühe römische Fibeln aus dem Alpenvorland und ihre chronologische Bedeutung für die Germanischen Kulturverhältnisse. In J. Werner (ed.), Aus Beyerns Frühzeit. Fridrich 
Wagner zum 75 Geburstag (= Schriftenreihe zur Bayerischen Landesgeschichte 62). Müchen, 125-137.

Kostrzewski J. 1919. Die ostgermanische Kultur der Spätlatèneziet (= Mannus-Bibliothek 18). Leipzig - Würzburg: C. Kabitzsch.

Kruk J. 1970. Badania poszukiwawcze i weryfikacyjne w górnym i środkowym dorzeczu Szreniawy. Sprawozdania Archeologiczne 22, 271-294.

Liana T. 1970. Chronologia względna kultury przeworskiej we wczesnym okresie rzymskim. Wiadomości Archeologiczne 35, 429-491.

Machajewski H. 1998. Die Fibeln der Gruppe V, Serie 8, im östlischen Teil Mitteleuropas. In: J. Kunow (ed.), 10o Jahre Fibelformen nach Oscar Almgren. Internationale Arbeitstagung 25.28. Mai 1997 in Kleinmachnow, Land Brandenburg (= Forschungen zur Archäologie im Land Brandenburg 5). Wünsdorf: Brandenburgisches Landesamt für Denkmalpflege und Archäologisches Landesmuseum, 187-201.

Madyda-Legutko R. 2011. Studia nad zróżnicowaniem metalowych części pasów w kulturze przeworskiej. Okucia końca pasa. Kraków: Instytut Archeologii Uniwersytetu Jagiellońskiego.

Mączyńska M. 1977. Paciorki z okresu rzymskiego i wczesnej fazy okresu wędrówek ludów na obszarze środkowoeuropejskiego Barbaricum. Archeologia 28, 61-91.

Martin M. 1994. Fibel und Fibeltracht. K. Späte Völkervanderungszeit und Merowingerzeit auf dem Kontinent. In H. Beck et al. (eds.), Reallexikon der Germanischen Altertumskunde 8. Berlin - New York: Walter de Gruyter, 541-582.

Megaw J. V. S. 1970. Art of the European Iron Age. A study of the elusive image. Bath: Adams \& Dart. Meller H. 2012. Die Fibeln aus dem Reitia-Heiligtum von Este (Ausgrabungen 1880-1916). Studien zu den SpätlaTèneformen / Le fibule del santuario di Reitia a Este (Scavi 1880-1916). Studi sulle forme tardo-Lateniane (= Studien zu Vor- und Früggeschichtlischen Heiligtümer 1,2). Mainz: Nünnerich-Asmus Verlag \& Media.

Micyk P. 2007. Monety rzymskie na osadach i cmentarzyskach ludności kultury przeworskiej. Kraków (typescript of Master Thesis stored at the Archives of Institute of Archaeology of Jagiellonian University).

Naglik R. 2001. Sprawozdanie z badań ratowniczych prowadzonych w związku z budową autostrady A-4 na terenie b. woj. krakowskiego i b. woj. tarnowskiego w latach 1996-1999. In Z. Bukowski (ed.), Raport 96-99. Wstępne wyniki konserwatorskich badań archeologicznych $w$ strefie budowy autostrad $w$ Polsce za lata 1996-1999 (= Zeszyty Ośrodka Ochrony dziedzictwa Archeologicznego, seria B: Materiały Archeologiczne). Warszawa: Ośrodek Ochrony Dziedzictwa Archeologicznego, 308-352.

Olędzki M. 1996. Naddunajska grupa kultury przeworskiej w świetle analizy materiałów archeologicznych. Acta Univesitatis Lodziensis - Folia Archaeologica 20, 49-67.

Olędzki M. 1998. Rollenkappenfibeln der östlischen Hauptserie Almgren 37-41 und die Varianten Fig. 43-43. In J. Kunow (ed.), 100 Jahre Fibelformen nach Oscar Almgren. Internationale Arbeitstagung 25--28. Mai 1997 in Kleinmachnow, Land Brandenburg (= Forschungen zur Archäologie im Land Brandenburg 5). Wünsdorf: Brandenburgisches Landesamt für Denkmalpflege und Archäologisches Landesmuseum, 67-84 . 
Pieta K. 2008. Keltské osidlenie Slovenska. Mladšia doba laténska (= Archaeologica Slovaca Monographiae - Studia 11). Nitra: AÚ Slovenskej Akadémie Vied.

Poleska P. 2006. Celtycki mikroregion osadniczy w rejonie podkrakowskim (=Biblioteka Muzeum Archeologicznego w Krakowie 2). Kraków: Muzeum Archeologiczne.

Rudnicki M. 2006. Importy rzymskie z Pełczysk. In E. Droberjar and O. Chvojka (eds.), Archeologie barbarů 2006, Sborník príspevků z II. protohistorické konference. České Budějovice 21.24.11.2006 (= Archeologické Výzkumy v Jizních Cechach, Supplementum 3/1). České Budějovice, $93-112$.

Rudnicki M. 2012. Finds and Context of Şimleul Silvaniei Type Bracelets North of the Carpathians and the Sudety. In S. Berecki (ed.), Iron Age Rites and Rituals in the Carpathian Basin. Proceedings of the international colloquium from Târgu Mureş 7-9 October 2011. Târgu Mureş: Editura MEGA.

Rudnicki M. and Miłek S. 2011. New evidence on contacts between Pre-Roman Dacia and territory of Central Poland. Acta Archaeologica Carpathica 46, 117-143.

Rustoiu A. 1991. Ein dakischer Bronzearmring im Norden Deutschlands, Thraco-Dacica 12, 143-147. Rustoiu A. 1992. O brățară dacică de la Şimleul Silvaniei, Acta Musei Porolissensis 16, 139-142.

Tejral J. 1992. Einige Bemerkungen zur Chronologie der späten römischen Kaiserzeit in Mitteleuropa. In K. Godłowski and R. Madyda-Legutko (eds.), Probleme der relativen und absoluten Chronologie ab LaTènezeit bis zum Frühmittelalter. Materialien des III. Internationalen Symposiums: Grundprobleme der frühgeschichtlichen Entwicklung im nördlichen Mitteldonaugebiet, Kraków-Karniowice 3.-7. Dezember 1990. Kraków: Instytut Archeologii Uniwersytetu Jagiellońskiego, 227-248.

Tejral J. 2006. Die germanische Gießerwerkstatt in Pasohlávky (Bez. Břeclav). Ein Beitrag zur Frage der Fernhandels- und Kulturbeziehungen nach den Markomannenkriegen. Památky Archeologické 97, 133-170.

Völling T. 1994. Studien zu Fibelformen der jüngeren vorrömischen Eisenzeit und ältesten römischen Kaiserzeit. Bericht der Römisch-Germanische Kommission 75, 147-282.

Waldhauser J. 1983. Závěrečný horizont keltských oppid v Čechách. (Konfrontacje výkladů historických pramenů, numismatiky a archeologie). Slovenská Archeologia 31(2), 325-356.

Woźniak Z. 1990. Osada grupy tynieckiej w Podłężu, woj. krakowskie. Wrocław - Warszawa - Kraków: Ossolineum.

Zagórska-Telega J. 200o. Bogaty pochówek kobiecy na cmentarzysku kultury przeworskiej w Opatowie, stanowisko 1, woj. śląskie. In. R. Madyda-Legutko and T. Bochank (eds.), Superiores Barbari. Księga pamiątkowa ku czci Profesora Kazimierza Godłowskiego. Kraków: Instytut Archeologii Uniwersytetu Jagiellońskiego, 313-326.

Żygadło L., Kamyszek L., Marciniak M. and Suchan G. 2012. Osadnictwo kultury lateńskiej i kultury przeworskiej na stanowisku 10-12 w Domasławiu, gm. Kobierzyce, woj. dolnośląskie. In S. Kadrow (ed.), Raport 2007-2008 1. Warszawa: Narodowy Instytut Dziedzictwa, 483-508. 
